УДК: 351.65

DOI:https://doi.org/10.32689/2618-0065-2020-2(4)-73-80

Височанський Михайло Рудольфович, головний оперуповноважений Департаменту стратегічних розслідувань Національної поліції України, м. Київ, вул. Богомольця, 10, e-mail: saozarp@protonmail.com, https//orcid.org/0000-0002-6028-2922

\title{
ВЗАЕМОДІЯ ПРАВООХОРОННИХ ТА ІНШИХ ОРГАНІВ ЯК ФАКТОР ЕФЕКТИВНОСТІ ВПЛИВУ НА ЕКОНОМІЧНУ БЕЗПЕКУ УКРАЇНИ
}

Анотація. У статті розглянуто питання, що стосуються взаємодії правоохоронних та інших органів, а також іiі вплив на зміцнення економічної безпеки загалом. Під поняттям взаємодія слід розуміти узгоджену діяльність, що під час виявлення, розкриття та розслідування кримінальних правопорушень здійснюється згідно основних принципів взаємодії. Умовно взаємодію під час розкриття та розслідування кримінальних правопорушень можна розглядати залежно від виду діяльності з якою вона пов’язана, а саме: 1) взаємодію між оперативними працівниками, слідчим, прокурором в якості процесуального керівника та слідчим суддею в рамках кримінального провадження; 2) взаємодію між органами досудового розслідування чи судом із спеціалістами, експертами та експертними установами; 3) взаємодію між правоохоронними органами чи установами у рамках міжнародного співробітництва. Розглянувши кожен із видів взаємодії та проблемні питання, що їх стосуються, у статті запропоновано варіанти вирішення цих питань. Так, щодо взаємодії, яка стосується здійснення процесуального керівництва прокурором, надання (виконання) доручень, отримання рішення слідчого судді запропоновано збільшити ресурси використання електронних технологій стосовно документообігу. У випадку взаємодії між органами досудового розслідування чи судом із спеціалістами, експертами та експертними установами запропоновано створити можливість проводити попередні експрес дослідження на місці виявлення кримінального правопорушення у разі потреби. Стосовно взаємодії в рамках міжнародного співробітництва, на нашу думку, державі слід приділити увагу налагоджуванні процесів саме непроцесуальної взаємодії між регіональними відділами, які безпосередньо приймають участь у розслідуваннях.

Враховуючи наведене, звернуто увагу на важливість ролі держави у вирішенні проблем взаємодії, вказаної вище, та необхідність здійснення державного регулювання цього питання. Під поняттям державне регулювання 
слід розуміти діяльність, що застосовується спеціально уповноваженими органами, врегульована нормами права та спрямована на забезпечення функціонування держави з урахуванням іiі цілісності, неподільності, прав та свобод громадян як найвищих соціальних цінностей.

Ключові слова: економічна безпека, правопорушення, правоохоронні органи, розслідування, державне регулювання.

Vysochanskiy Mikhail Rudolfovych, chief operating officer, Department of Strategic Investigation of the National Police of Ukraine, Kyiv, Str. Bohomol'tsa, 10, e-mail: saozarp@protonmail.com, https//orcid.org/0000-0002-6028-2922

\section{INTERACTION OF LAW ENFORCEMENT AND OTHER AUTHORITIES AS A FACTOR OF THE EFFECTIVENESS OF EFFECT ON ECONOMIC SECURITY OF UKRAINE}

Abstract. The article deals with issues related to the interaction of law enforcement and other bodies, as well as its impact on strengthening economic security in general. The concept of interaction should be understood as the concerted activity that, when detecting, disclosing and investigating criminal offenses, is carried out in accordance with the basic principles of interaction. Conditional interaction in the detection and investigation of criminal offenses can be considered depending on the type of activity with which it is related, namely: 1) interaction between operatives, investigator, prosecutor as a procedural leader and investigating judge in criminal proceedings; 2) interaction between pre-trial investigative bodies or court with specialists, experts and expert institutions; 3) interaction between law enforcement agencies or institutions in the framework of international cooperation. Having considered each of the types of interaction and the problematic issues related to them, the article offers options for solving these issues. Thus, with regard to the interaction related to the exercise of procedural guidance by the prosecutor, the submission (execution) of orders, obtaining the decision of the investigating judge, it is proposed to increase the resources of using electronic technologies in relation to the circulation of documents. In case of interaction between the pre-trial investigation bodies or the court with specialists, experts and expert institutions, it is suggested to create an opportunity to conduct preliminary express investigation at the place of detection of the criminal offense if necessary. With regard to cooperation in the framework of international cooperation, in our opinion, the state should pay attention to the establishment of processes of non-procedural cooperation between regional departments that are directly involved in investigations.

In view of the above, the importance of the state's role in solving the problems of interaction mentioned above and the need for state regulation of this issue have been emphasized. The concept of state regulation should be understood as an activity used by specially authorized bodies, regulated by the rules of law and aimed at 
ensuring the functioning of the state, taking into account its integrity, indivisibility, rights and freedoms of citizens as the highest social values.

Keywords: economic security, offenses, police, investigations, state regulation.

Постановка проблеми. У сучасному світі, в тому числі в Україні, боротьба із кримінальними правопорушеннями у сфері економіки необхідна для зміцнення фундаменту економічної безпеки та у більшості випадків проводиться за умови взаємодії в процесі роботи правоохоронних органів. Безумовно якість цієї взаємодії впливає на виявлення розкриття та розслідування економічних злочинів, а в кінцевому рахунку - на організацію економічної безпеки держави загалом. Таким чином питання ії покращення $\epsilon$ актуальним, а враховуючи наявність збитків, що можуть бути завдані в результаті вчинених фінансових кримінальних правопорушень, необхідним. Також, звернемо увагу, що в сфері економіки шкода завдається переважно у великих або особливо великих розмірах, окрім такі правопорушення можуть бути пов’язаними із не поступленням коштів у бюджет країни, що в свою чергу породжує похідні негативні наслідки.

Враховуючи наведене, взаємодія між органами під час розслідування правопорушень у сфері економіки $є$ досить важливою та $є$, на наш погляд, неможливою без створення сприятливих умов з боку держави. Саме тому слід приділити увагу проблемам взаємодії та на державному рівні впливати на організацію діяльності правоохоронних органів враховуючи при цьому позитивний досвід зарубіжних країн.

Аналіз останніх досліджень і публікацій. У випадку дослідження питань взаємодії під час розкриття та розслідування кримінальних правопорушень найбільше уваги приділяють вчені процесуалісти, оскільки така взаємодія часто відбувається в межах кримінально-процесуальної діяльності. Так, різні аспекти взаємодії вивчали С.Є. Абламський, А.М.Ю. Ангеленюк, Т.Ф. Безсонна, А.І. Кунтій, С.А. Левенець, О.В. Линник, Ю.В. Лук'яненко, О.О. Юхно та інші.

Метою статті $\epsilon$ дослідження проблемних питань взаємодії між органами під час розкриття та розслідування кримінальних правопорушень; визначення ролі взаємодії між органами та іiї впливу на забезпечення економічної безпеки країни загалом; формування пропозицій щодо вдосконалення зазначеної взаємодії.

Виклад основного матеріалу. У системі МВС України взаємодія здійснюється в рамках Кримінального процесуального кодексу України від 13.04.2012 (далі - КПК), Закону України «Про Національну поліцію» від 02.07.2015, Інструкції з організації взаємодії органів досудового розслідування з іншими органами та підрозділами Національної поліції України в запобіганні кримінальним правопорушенням, їх виявленні та розслідуванні (далі - 
Інструкція), затвердженої наказом Міністерства внутрішніх справ України № 575 від 07.07.2017, а також інших нормативно правових актів.

Під поняттям взаємодія слід розуміти узгоджену діяльність, що під час виявлення, розкриття та розслідування кримінальних правопорушень здійснюється згідно основних принципів взаємодії, які закріплені в ст. 3 Інструкції, а саме: 1) швидке, повне та неупереджене розслідування кримінальних правопорушень; 2) самостійність слідчого в процесуальній діяльності, втручання в яку осіб, що не мають на те законних повноважень, забороняється; 3) оптимальне використання наявних можливостей органів досудового розслідування та оперативних підрозділів Національної поліції України у запобіганні, виявленні та розслідуванні кримінальних правопорушень; 4) дотримання загальних засад кримінального провадження; 5) забезпечення нерозголошення даних досудового розслідування [1].

Завданнями взаємодії органів досудового розслідування 3 іншими органами та підрозділами Національної поліції України, згідно ст. 1 Інструкції, визначено запобігання вчиненню кримінальних правопорушень, їх виявлення та розслідування, притягнення до встановленої законодавством відповідальності осіб, які їх учинили, відшкодування завданої кримінальними правопорушеннями шкоди, відновлення порушених прав та інтересів фізичних і юридичних осіб [1].

Умовно взаємодію під час розкриття та розслідування кримінальних правопорушень можна розглядати залежно від виду діяльності з яким вона пов'язана, а саме:

- взаємодію між оперативними працівниками, слідчим, прокурором в якості процесуального керівника та слідчим суддею в рамках кримінального провадження;

- взаємодію між органами досудового розслідування чи судом із спеціалістами, експертами та експертними установами;

- взаємодію між правоохоронними органами чи установами у рамках міжнародного співробітництва.

Взаємодія фактично може здійснюватись не тільки у процесуальній формі, а й у непроцесуальній. Процесуальна форма взаємодії організована згідно правових норм, які врегульовують порядок іiі здійснення в окремих випадках. Непроцесуальна взаємодії, на відміну від процесуальної, не закріплена в нормах права, але випливає 3 них, а також 3 правоохоронної практики. Переважно реалізація непроцесуальної форми взаємодії відбувається у випадку встановлених особистих контактів, які, зазвичай формуються із взаємин між керівниками відповідного рівня. До видів непроцесуальної форми взаємодії під час розслідування відносять: надання консультацій; спільне обговорення матеріалів провадження; обмін інформацією [2, с. 353]. 
Пропонуємо під час виявлення, розкриття та розслідування кримінальних правопорушень поділяти взаємодію залежно від сфери застосування:

1) під час процесуального керівництва та надання доручень, здійснення спільних заходів, слідчих чи процесуальних дій (взаємодія між слідчим, прокурором, оперативним працівником, слідчим суддею);

2) з спеціалістами, експертами, експертними установами;

3) в рамках міжнародного співробітництва.

Зауважимо, що згідно КПК від 2012 року було запроваджено інститут процесуального керівництва та прийняття частини рішень по кримінальному провадженні виключно судом. Так, слідчий зобов'язаний із багатьох питань звертатись за дозволом в суд, а також, у ряді випадків, перед зверненням в суд, погоджувати клопотання 3 процесуальним керівником-прокурором (обрання запобіжних заходів, проведення деяких слідчих дій і т.д.). Окрім, згідно ст. 41 КПК оперативні підрозділи здійснюють слідчі дії за письмовим дорученням слідчого чи прокурора та не мають права виконувати процесуальні дії за власною ініціативою [4]. Такий спектр дій передбачає збільшення платформи взаємодії між вказаними вище суб'єктами. Проблемним питанням цього виду взаємодії $є$ збільшення робочого навантаження на учасників, а тому слід на державному рівні вирішувати питання щодо збільшення їх штату або оптимізації діяльності, наприклад за допомогою використання електронних носіїв (введення електронних підписів, електронного провадження, електронного документообігу і т.д.). Усі перелічені дії потребують державного регулювання, так як слід залучати об'ємні технологічні чи інтелектуальні ресурси.

Під державним регулюванням слід розуміти діяльність, що застосовується спеціально уповноваженими органами, врегульована нормами права та спрямована на забезпечення функціонування держави з урахуванням iї цілісності, неподільності, прав та свобод громадян як найвищих соціальних цінностей.

Стосовно наступного виду взаємодії 3 спеціалістами, експертами, експертними установами у частині випадків проблематикою є можливість отримання консультацій під час виявлення чи розкриття кримінального правопорушення. Наприклад під час виявлення у особи речовини, схожої на наркотичну щодо якої ще немає даних експертизи, було б добре мати можливість працівникам правоохоронних органів провести попереднє експрес дослідження речовини на місці. Однак у сучасних реаліях така процедура не передбачена та $\epsilon$ неможливою 3 технічних причин (відсутність матеріалів, інструментарію для проведення експрес дослідження на місці; відсутність необхідних навиків у працівників правоохоронних органів, які безпосередньо виявляють та розкривають кримінальні правопорушення). 
Звичайно, процес збору доказів передбачає їх виявлення, фіксацію i вилучення у чому саме допомагають криміналістичні засоби і методи, проте слід зауважити, що ефективність застосування криміналістичних засобів та методів, зокрема під час розслідувань залежить від реальних можливостей їх застосування. У цьому випадку ефективною є взаємодія органів досудового розслідування 3 експертами та спеціалістами, що можуть надавати консультативну допомогу як у рамках кримінального провадження, так і в процесі виявлення чи розкриття злочину до початку досудового розслідування як стадії. Проте на державному рівні слід передбачити проведення попередніх експрес досліджень, які могли б проводити правоохоронці самостійно у разі необхідності. Консультативна допомога з боку спеціалістів та експертів може відбуватись в рамках проведення курсів підвищення кваліфікації для працівників правоохоронної системи. Також було б доцільно розробити комплекти для проведення попередніх експрес досліджень на офіційному рівні залучившись підтримкою держави.

Враховуючи тенденції глобалізації в сучасному світі без перебільшення можна стверджувати, що одне 3 основних є міжнародне співробітництво між країнами, що має місце у багатьох сферах діяльності держав. Не винятком $є$ і Україна. Безперечно, взаємодія під час використання міжнародного співробітництва $є$ досить важливо. На нашу думку в Україні недостатньо уваги приділено непроцесуальній формі такого співробітництва.

Зауважимо, що у багатьох країнах створено вузько-направлені органи, які вирішують конкретне коло питань, 3 метою досягнення загальної стабільності та розвитку держави.

Так, у США певні інституції надають допомогу в справах стосовно повернення активів, зокрема:

- Міністерство юстиції США, Кримінальне відділення, Відділ з питань повернення активів та боротьби з легалізацією доходів (AFMLS);

- Міністерство юстиції США, Кримінальне відділення, Управління міжнародних справ (ОIA);

- Міністерство національної безпеки США, Відділ розслідувань імміграційних та митних правопорушень (HSI);

- Міністерство юстиції США, Федеральне бюро розслідувань (FBI) [3, c. 153].

В Україні ж широкі повноваження у наданні міжнародно-правової допомоги та здійсненні міжнародно-правового співробітництва $є$ у Генеральної прокуратури або Міністерства юстиції які у відповідний момент виступають у якості центрального уповноваженого органу [4]. Однак, непроцесуальна взаємодія на нижчих рівнях між органами різних країн, які безпосередньо провадять досудові розслідування, відбувається вкрай рідко, переважно базується на використанні особистих взаємовідносинах конкретних працівників, що, переважно, $є$ представниками країн-сусідів. 
Безперечно, окрім офіційної процедури здійснення міжнародного співробітництва важливе значення займає налагодження особистих зв'язків 3 іноземними колегами, що є запорукою у виконанні тих чи інших поставлених завдань.

Особисті зв’язки також допомагають продемонструвати серйозність підходу, зацікавленість у робочому процесі, сприяють встановленню довіри між сторонами. Для встановлення контакту слід звернути увагу на колег аналогічних структур іноземних держав.

Вважаємо, що до налагодження особистих зв'язків між сторонами іноземних країн на рівні відділів (відділень), що безпосередньо розслідують більше слід долучатись й на державному рівні та відповідно регулювати ці процеси. Наприклад, організовувати у більшій кількості тематичні конференції, семінари і т.д. 3 обов'язковою участю практичних працівників різних держав. Також, з метою економії коштів та часу учасників, що мали б здійснювати переїзд до місця проведення такого заходу, можна передбачити його проведення з допомогою відео-конференції.

Вказаний вище формат конференцій допоможе частково вирішити питання пов'язані з факторами, що можуть перешкоджати міжнародному співробітництву. Наприклад такими як юридичні перепони; наявність подвійної підсудності; надмірна тривала процедура офіційного порядку застосування та іншими.

Взаємодія правоохоронних органів полегшує співпрацю між регіонами, а регіональна поліцейська співпраця $є$ невід'ємною частиною операційного середовища сьогодні [5], оскільки країни в регіоні часто поділяють кордони, мови, однак наявні подібні загрози в результаті вчинення кримінальних правопорушень.

Висновки. Розглядаючи взаємодію між органами під час виявлення, розкриття та розслідування кримінальних правопорушень доцільно поділити їх на види залежно від сфери застосування. Залежно від проблем використання зазначеної вище взаємодії у статті запропоновано напрямки їх часткового вирішення.

Так, щодо взаємодії, яка стосується здійснення процесуального керівництва, надання (виконання) доручень, отримання рішення слідчого судді запропоновано збільшити ресурси використання електронних технологій.

У випадку взаємодії між органами досудового розслідування чи судом із спеціалістами, експертами та експертними установами запропоновано створити можливість проводити попередні експрес дослідження на місці виявлення кримінального правопорушення у разі потреби.

Стосовно взаємодії в рамках міжнародного співробітництва, на нашу думку, державі слід приділити увагу налагоджуванні процесів саме непроцесуальної взаємодії між регіональними відділами, які безпосередньо 
приймають участь у розслідуваннях, що сприятиме покращенню економічної безпеки України загалом.

Вирішення проблем пов'язаних із здійсненням взаємодії позитивно вплине на зміцнення економічної безпеки України загалом.

\section{Лimepamypa:}

1. Інструкція з організації взаємодії органів досудового розслідування з іншими органами та підрозділами Національної поліції України в запобіганні кримінальним правопорушенням, їх виявленні та розслідуванні, затвердженої наказом Міністерства внутрішніх справ України № 575 від 07.07.2017. URL: https://zakon.rada.gov.ua/laws/show/z0937-17

2. Пясковський В.В. Особливості непроцесуальної форми взаємодії слідчих 3 підрозділами кримінальної поліції та ювенальної превенції під час розслідування насильницьких злочинів, учинених щодо неповнолітніх.C 352-354. URL:http://elar.naiau.kiev.ua/bitstream/123456789/15409/1/\%D0\%97\%D0\%91\%D0\%86\%D0\%A0\% D0\%9D\%D0\%98\%D0\%9A\%2027_11_2019_p352-354.pdf

3. Фінансові розслідування у сфері протидії легалізації злочинних доходів в Україні [Текст] : метод. рек. / [С. С. Чернявський, О. С. Користін, В. А. Некрасов та ін.]. - Київ : Нац. акад. внутр. справ, 2017. - 164 с.

4. Кримінальний процесуальний кодекс України від 13.04.2012 URL: zakon.rada.gov.ua/laws/show/4651-17 (дата звернення 31.01.2020).

5. Інтерпол. Наші партнерські стосунки 3 регіональними органами правоохоронних органів URL: https://www.interpol.int/en/Our-partners/

\section{References:}

1. Nakaz Ministerstva vnutrishnikh sprav Ukrainy "Instruktsiia z orhanizatsii vzaiemodii orhaniv dosudovoho rozsliduvannia z inshymy orhanamy ta pidrozdilamy Natsionalnoi politsii Ukrainy v zapobihanni kryminalnym pravoporushenniam, yikh vyiavlenni ta rozsliduvanni” : vid 07.07.2017, № 575 [Order of the Ministry of Internal Affairs of Ukraine "Instruction on the organization of interaction of pre-trial investigation bodies with other bodies and units of the National Police of Ukraine in the prevention of criminal offenses, their detection and investigation" from 07.07.2017, № 575]. zakon.rada.gov.ua. Retrieved from https://zakon.rada.gov.ua/laws/show/z0937-17 [in Ukrainian].

2. Piaskovskyi, V.V. (2019). Osoblyvosti neprotsesualnoi formy vzaiemodii slidchykh z pidrozdilamy kryminalnoi politsii ta yuvenalnoi preventsii pid chas rozsliduvannia nasylnytskykh zlochyniv, uchynenykh shchodo nepovnolitnikh [Features of non-procedural form of interaction of investigators with criminal police and juvenile prevention units in the investigation of violent crimes committed against minors]. Teoriia ta praktyka sudovoekspertnoi diialnosti - Theory and practice of expert activity : 8th Interagency Scientific Conference. (pp. 352-354). Kyiv. Retrieved from http://elar.naiau.kiev.ua/bitstream/123456789/15409/1/\%D0\%97\%D0\%91\%D0\%86\%D0\%A0\%D0\% 9D\%D0\%98\%D0\%9A\%2027_11_2019_p352-354.pdf [in Ukrainian].

3. Cherniavskyi, S.S., Korystin, O.Ye., Nekrasov, V.A., et al. (2017). Finansovi rozsliduvannia u sferi protydii lehalizatsii zlochynnykh dokhodiv v Ukraini [Financial Investigations in the Field of Combating the Legalization of Crime Income in Ukraine]. Kyiv: Nats. akad. vnutr. sprav [in Ukrainian].

4. Kryminalnyi protsesualnyi kodeks Ukrainy : vid 13.04.2012 [Criminal Procedure Code of Ukraine dated 13.04.2012]. zakon.rada.gov. Retrieved from zakon.rada.gov.ua/laws/show/4651-17 [in Ukrainian].

5. Interpol. Nashi partnerski stosunky z rehionalnymy orhanamy pravookhoronnykh orhaniv [Interpol. Our partnerships with regional law enforcement]. www.interpol.int. Retrieved from https://www.interpol.int/en/Our-partners/ [in Ukrainian]. 